\title{
The value of fertility-sparing surgery for young females with epithelial ovarian cancer: a comparative study
}

\author{
Wartość leczenia operacyjnego z zachowaniem płodności u młodych kobiet \\ z nabłonkowym rakiem jajnika: badanie porównawcze
}

\author{
'Department of Gynecology and Obstetrics, Zagazig University Faculty of Medicine, Zagazig, Egypt \\ ${ }^{2}$ Department of General Surgery, Zagazig University Faculty of Medicine, Zagazig, Egypt \\ ${ }^{3}$ Department of Clinical Oncology and Nuclear Medicine, Faculty of Medicine, Zagazig, Egypt \\ ${ }^{4}$ Department of Pathology, Zagazig University Faculty of Medicine, Zagazig, Egypt \\ Correspondence: Ola A. Harb, assistant professor of Pathology Faculty of Medicine, Zagazig University, Zagazig, Egypt, 44519, tel.: 01256895432, e-mail: olaharb2015@gmail.com
}

\begin{abstract}
Background: Epithelial ovarian cancer is increasingly often diagnosed in young females who wish to preserve their fertility. Fertilitypreserving surgeries, where conservation of the uterus and contralateral ovary was performed, might be beneficial for patients with stage I epithelial ovarian cancer, but their safety is still controversial. In the present study, we aimed to compare radical surgery and fertility-saving surgery in females with stage IA-C epithelial ovarian cancer for recurrence and survival rates, as well as to evaluate reproductive and obstetric outcomes for stage I epithelial ovarian cancer females who were managed with fertility-saving surgery. Materials and methods: We prospectively identified 60 patients aged $\leq 40$ years who were diagnosed with stage I epithelial ovarian cancer. The patients in the fertility-preservation group underwent salpingo-oophorectomy on the side of the affected ovary in addition to incisional biopsy or wedge excision of the ovary on the other side. The patients in the radical surgery group underwent total hysterectomy and bilateral salpingo-oophorectomy. We followed up all patients for 5 years to assess their reproductive and oncological outcomes. Results: Patients in the fertility preservation surgery group were significantly younger (30 \pm 4 versus $35 \pm$ 5 years) $(p<0.001)$, their tumor sizes were smaller $(3.4 \pm 1.3$ versus $6.0 \pm 2.6 \mathrm{~cm})(p<0.001)$, of lower grade $(p=0.011)$, earlier stage $(p<0.001)$ and had more mucinous histology than patients in the radical surgery group. There were no statistically significant differences between both groups regarding tumor recurrence or survival rates. Of 25 patients who underwent fertility preservation surgery, 18 (72\%) attempted to conceive. A total of 15/18 (83\%) pregnancies were recorded, including 13 live births, 1 miscarriage, and 1 intrauterine fetal death. Conclusion: Fertility-sparing surgery could be an adequate alternative to radical surgery for young females with stage I epithelial ovarian cancer.
\end{abstract}

Keywords: epithelial ovarian cancer, fertility preservation, radical surgery, outcome

Streszczenie Wstęp: Nabłonkowy rak jajnika stanowi coraz częstsze rozpoznanie u młodych kobiet, którym zależy na zachowaniu płodności. Zabiegi operacyjne z oszczędzeniem funkcji rozrodczych, w których zachowuje się macicę i drugi jajnik, mogą okazać się korzystne w przypadku pacjentek z nabłonkowym rakiem jajnika w stopniu zaawansowania I, choć bezpieczeństwo takiego postępowania nadal budzi kontrowersje. Autorzy niniejszej pracy porównali leczenie radykalne z operacją z zachowaniem płodności u kobiet z nabłonkowym rakiem jajnika w stopniu zaawansowania IA-C pod kątem wystąpienia nawrotów i przeżywalności, jak również ocenili wpływ leczenia na płodność i przebieg ciąży u pacjentek poddanych zabiegowi chirurgicznemu z zachowaniem płodności. Materiał i metody: Prospektywnie zidentyfikowano 60 pacjentek w wieku do 40 lat, u których rozpoznano nabłonkowego raka jajnika I stopnia. Pacjentki z grupy objętej leczeniem z zachowaniem płodności poddano salpingoowariektomii po stronie chorego jajnika oraz biopsji nacięciowej lub resekcji klinowej po stronie przeciwległej. U pacjentek z grupy objętej leczeniem radykalnym wykonano zabieg histerektomii całkowitej z obustronną salpingoowariektomią. Wszystkie pacjentki objęto 5-letnią obserwacją w celu dokonania oceny wpływu na płodność i przebieg ciąży. Wyniki: Pacjentki z grupy leczonej z zachowaniem płodności były znacznie młodsze (30 $\pm 4 v s 35 \pm 5$ lat) $(p<0,001)$, charakteryzowały się mniejszymi wymiarami guza $(3,4 \pm 1,3$ vs $6,0 \pm 2,6)(p<0,001)$, niższym stopniem złośliwości histologicznej $(p=0,011)$, niższym stopniem zaawansowania choroby $(p<0,001)$ oraz częstszym występowaniem śluzowego typu histologicznego guza niż pacjentki z grupy leczonej radykalnie. Nie stwierdzono żadnych statystycznie istotnych różnic między obiema grupami w odniesieniu do wystąpienia nawrotów choroby i przeżywalności. Spośród 25 pacjentek poddanych leczeniu chirurgicznemu z zachowaniem 
płodności 18 (72\%) kobiet podjęło starania o zajście w ciążę. Odnotowano 15/18 (83\%) ciąż, w tym 13 urodzeń żywych, 1 poronienie i 1 przypadek wewnątrzmacicznego obumarcia płodu. Wniosek: Leczenie chirurgiczne z zachowaniem płodności może stanowić dobrą alternatywę operacji radykalnej u młodych kobiet z rozpoznaniem raka jajnika I stopnia.

Słowa kluczowe: nabłonkowy rak jajnika, zachowanie płodności, operacja radykalna, wyniki leczenia

\section{INTRODUCTION}

$\mathrm{E}$ pithelial ovarian cancer (EOC) is mostly encountered in postmenopausal women, but it could be diagnosed at any age ${ }^{(1,2)}$. The definitive surgical management of EOC is total hysterectomy, bilateral salpingo-oophorectomy, lymphadenectomy, and omentectomy followed by adjuvant chemotherapy ${ }^{(3)}$. Recently, EOC has been diagnosed in a large number of young premenopausal females, with about $14 \%$ of cases occurring in females younger than 40 years, most of whom were nulliparous and might wish to preserve their fertility ${ }^{(4)}$. It was found that $7-8 \%$ of stage I EOC patients were younger than 35 years ${ }^{(5)}$. Fertility-sparing surgeries (FSS) might be beneficial for patients with stage I EOC, where conservation of the uterus and contralateral ovary was performed ${ }^{(6)}$.

Recent National Comprehensive Cancer Network (NCCN) guidelines stated that patients with unilateral stage (IA-C) EOC could undergo FSS regardless of histopathology or grade of their tumor ${ }^{(7)}$. The European Society of Medical Oncology (ESMO) stated that young females with stage IA-C EOC with only non-clear cell carcinoma histology and low grade can undergo FSS only after complete surgical staging and lymphadenectomy ${ }^{(8)}$. However, the safety of FSS is still controversial, even in low grade tumors with favorable histology.

In the present study, we aimed to compare radical surgery and fertility-saving surgery in females with stage IA-C EOC for recurrence and survival rates, as well as to evaluate reproductive and obstetric outcomes for stage I EOC females who underwent FSS.

\section{MATERIALS AND METHODS}

The study design was approved by local ethics committees of Faculty of Medicine, Zagazig University. We prospectively identified patients diagnosed with stage I EOC, aged $\leq 40$ years, who were admitted to the Department of Obstetrics and Gynecology of Zagazig University Hospitals in the period between 2012 and 2017. The diagnoses, as well as clinical and histopathological staging were assessed based on the World Health Organization Classification of Female Reproductive Organs Tumors $4^{\text {th }}$ edition and International Federation of Gynecology and Obstetrics (FIGO) staging system (2014).

\section{General inclusion criteria of the study}

Females with stage IA-C EOC of serous, mucinous or endometroid histology.

\section{Inclusion criteria for FSS}

Nulliparous patients at childbearing age with a strong desire to maintain their fertility and a certain diagnosis of stage I EOC were proposed FSS. If the patients refused to be treated with the conservative approach or they were postmenopausal, they underwent radical surgery.

\section{Exclusion criteria}

- Patients with clear cell carcinoma, borderline EOC, squamous cell carcinoma, germ cell tumor, sex cord stromal tumors of the ovary.

- Patients with incomplete clinical, pathological and follow-up data.

Patients in the FSS group underwent salpingo-oophorectomy on the side of the affected ovary in addition to incisional biopsy or wedge excision of the ovary on the other side. Since blind biopsy of the contralateral ovary in ovarian cancer patients receiving fertility-spearing treatment is not a routine procedure, it was done only in the case of grossly suspicious ovarian lesions.

Wedge excision of the contralateral ovary was limited to patients with stages IA and IB.

Patients in the radical surgery group underwent total hysterectomy and bilateral salpingo-oophorectomy.

We performed complete surgical staging for both groups by performing omentectomy, lymphadenectomy, appendectomy, peritoneal washings, and multiple random omental biopsies. Evaluation of all pathological slides was performed by two expert pathologists without previous knowledge of the clinical data or patient outcomes. Adjuvant chemotherapy was given after surgery to patients at high risk for recurrence as patients with: FIGO stage IC or high grade tumors or tumors with focal clear-cell morphology. Chemotherapy regimen composed of TC (paclitaxel and carboplatin) and PC (cyclophosphamide and cisplatin); the number of cycles ranged from 4 to 6 cycles. After finishing primary treatment we followed-up patients monthly for the first six months, every two months for the first year, every six months for another two years, and then yearly for five years. During the follow-up visits, we performed complete clinical examination, pelvic examination, ultrasound scan and evaluation of serum tumor marker CA-125.

Recurrence was confirmed by histopathological evidence of tumor in recently acquired incisional or fine-needle biopsy, or recently detected lesions during radiological evaluation. 


\begin{tabular}{|c|c|c|c|c|c|c|c|c|}
\hline & & \multicolumn{4}{|c|}{ Operation } & \multirow{3}{*}{\multicolumn{2}{|c|}{$\begin{array}{c}\text { Total } \\
N=60\end{array}$}} & \multirow{4}{*}{$p$} \\
\hline & & \multicolumn{2}{|c|}{ Conservative surgery } & \multicolumn{2}{|c|}{ Radical surgery } & & & \\
\hline & & $n=25$ & & $n=35$ & & & & \\
\hline & & $n$ & $\%$ & $n$ & $\%$ & $n$ & $\%$ & \\
\hline \multicolumn{9}{|c|}{ Clinicopathological } \\
\hline \multicolumn{2}{|c|}{ Age [years] } & \multicolumn{2}{|c|}{$30 \pm 4$} & \multicolumn{2}{|c|}{$35 \pm 5$} & \multicolumn{2}{|c|}{$32 \pm 8$} & $<0.001$ \\
\hline \multirow{3}{*}{ Histopathology } & Endometroid & 3 & $12.0 \%$ & 4 & $11.4 \%$ & 7 & $11.7 \%$ & \multirow{3}{*}{0.582} \\
\hline & Mucinous & 7 & $28.0 \%$ & 6 & $17.1 \%$ & 13 & $21.7 \%$ & \\
\hline & Serous & 15 & $60.0 \%$ & 25 & $71.4 \%$ & 40 & $66.7 \%$ & \\
\hline \multirow{2}{*}{ Parity } & Nulli & 25 & $100.0 \%$ & 10 & $28.6 \%$ & 35 & $58.3 \%$ & \multirow{2}{*}{$<0.001$} \\
\hline & Multi & 0 & $0.0 \%$ & 25 & $71.4 \%$ & 25 & $41.7 \%$ & \\
\hline \multirow{2}{*}{ Side of tumor } & Uni & 25 & $100.0 \%$ & 24 & $68.6 \%$ & 49 & $81.7 \%$ & \multirow{2}{*}{0.002} \\
\hline & Bilat. & 0 & $0.0 \%$ & 11 & $31.4 \%$ & 11 & $18.3 \%$ & \\
\hline \multicolumn{2}{|c|}{ Size $[\mathrm{cm}]$} & \multicolumn{2}{|c|}{$3.4 \pm 1.3$} & \multicolumn{2}{|c|}{$6.0 \pm 2.6$} & \multicolumn{2}{|c|}{$4.9 \pm 2.5$} & $<0.001$ \\
\hline \multirow{4}{*}{ FIGO stage } & Stage IA & 12 & $48.0 \%$ & 0 & $0.0 \%$ & 12 & $20 \%$ & \multirow{4}{*}{$<0.001$} \\
\hline & Stage IB & 11 & $44.0 \%$ & 14 & $40 \%$ & 25 & $42 \%$ & \\
\hline & Stage IC & 2 & $0.08 \%$ & 20 & $57 \%$ & 22 & $36 \%$ & \\
\hline & Stage IIB & 0 & $0.0 \%$ & 1 & $0.02 \%$ & 1 & $1.7 \%$ & \\
\hline \multirow{2}{*}{ Grade } & High grade & 6 & $24.0 \%$ & 20 & $57.1 \%$ & 26 & $43.3 \%$ & \multirow{2}{*}{0.011} \\
\hline & Low grade & 19 & $76.0 \%$ & 15 & $42.9 \%$ & 34 & $56.7 \%$ & \\
\hline \multirow{2}{*}{$\begin{array}{c}\text { Number of } \\
\text { chemotherapy cycles }\end{array}$} & 4 & 6 & $24.0 \%$ & 8 & $22.9 \%$ & 14 & $23.3 \%$ & \multirow{2}{*}{0.918} \\
\hline & 6 & 19 & $76.0 \%$ & 27 & $77.1 \%$ & 46 & $76.7 \%$ & \\
\hline \multicolumn{9}{|c|}{ Outcome } \\
\hline \multirow{2}{*}{ Recurrence } & 0 & 20 & $80.0 \%$ & 27 & $77.1 \%$ & 47 & $78.3 \%$ & \multirow{2}{*}{0.791} \\
\hline & 1 & 5 & $20.0 \%$ & 8 & $22.9 \%$ & 13 & $21.7 \%$ & \\
\hline \multirow{2}{*}{ Death } & 0 & 22 & $88.0 \%$ & 30 & $85.7 \%$ & 52 & $86.7 \%$ & \multirow{2}{*}{0.797} \\
\hline & 1 & 3 & $12.0 \%$ & 5 & $14.3 \%$ & 8 & $13.3 \%$ & \\
\hline
\end{tabular}

Tab. 1. A comparison between patients who underwent both surgical techniques regarding clinicopathological features and treatment outcomes of patients

Disease-free survival (DFS) rate was calculated from primary surgery time to disease recurrence. Cancer-specific survival (CSS) rate was calculated from primary surgery to cancer specific death or censoring during the last follow-up. Statistical analysis: The collected data were computerized and statistically analyzed using Statistical Package for Social Sciences (SPSS 24 Inc. Chicago, IL, USA). Data were tested for normal distribution using the Shapiro-Wilk test. Qualitative data were represented as frequencies and relative percentages. Chi square test $\left(\chi^{2}\right)$ and Fisher exact were used to calculate differences between qualitative variables as indicated. Quantitative data were expressed as mean \pm $S D$ (standard deviation). A $p$-value $\leq 0.05$ indicates significant, $p<0.001$ indicates highly significant difference while, $p>0.05$ indicates non-significant difference.

Survival analysis: Kaplan and Meier method was used to estimate overall and event-free survival and log rank test compared survival curves. Overall survival (OS) was calculated as the interval between the date of diagnosis and the date of death or last follow-up. Recurrence-free survival (RFS) was calculated from the date of documented complete response to therapy, till relapse date, or the end date of the study.

\section{RESULTS}

The present study included 60 patients - 25 (45\%) patients underwent FSS and 35 (55\%) patients underwent radical surgery (Tab. 1).

Patients in the FSS group were significantly younger (30 \pm 4 versus $35 \pm 5$ years $)(p<0.001)$, their tumor sizes were smaller $(3.4 \pm 1.3$ versus $6.0 \pm 2.6 \mathrm{~cm})(p<0.001)$, of lower grade $(p=0.011)$, earlier stage $(p<0.001)$ and had more mucinous histology compared to the radical surgery group. All patients in the FSS group were nulliparous, while most patients in the radical surgery group were multiparous $(p<0.001)$.

The number of patients on chemotherapy was higher in the radical surgery group than FSS group.

\section{A comparison of both groups for oncologic outcomes}

After a median follow-up period of 56 months (range, 25-60 months), of all included patients $13(21.7 \%)$ patients relapsed, and $8(13.3 \%)$ died of the disease. The relapsed patients were of high grade and FIGO stage IC and IIB. 


\begin{tabular}{|c|c|c|c|c|c|c|c|c|c|}
\hline \multirow{3}{*}{ Operation } & \multirow{3}{*}{$\begin{array}{c}\text { Total } \\
n\end{array}$} & \multirow{3}{*}{$\begin{array}{l}\text { Number } \\
\text { of events }\end{array}$} & \multicolumn{2}{|c|}{ Censored } & \multirow{3}{*}{$\begin{array}{l}\text { Survival } \\
\text { rate [\%] }\end{array}$} & \multirow{3}{*}{ Sig. } & \multicolumn{3}{|c|}{ Survival time [months] } \\
\hline & & & \multirow{2}{*}{$n$} & \multirow{2}{*}{ Percent } & & & \multicolumn{2}{|c|}{ Mean } & \multirow{2}{*}{ Mediar } \\
\hline & & & & & & & Estimate $\pm S E$ & $95 \% \mathrm{Cl}$ & \\
\hline \multicolumn{10}{|c|}{ Overall survival } \\
\hline Conservative surgery & 25 & 3 & 22 & $88.0 \%$ & $80.8 \%$ & \multirow{2}{*}{0.848} & $58.9 \pm 0.6$ & $57.7-60.1$ & NR \\
\hline Radical surgery & 35 & 5 & 30 & $85.7 \%$ & $70.7 \%$ & & $59.0 \pm 0.4$ & $58.1-59.8$ & NR \\
\hline Overall & 60 & 8 & 52 & $86.7 \%$ & $74.8 \%$ & & $58.9 \pm 0.4$ & $58.2-59.6$ & NR \\
\hline \multicolumn{10}{|c|}{ Recurrence free survival } \\
\hline Conservative surgery & 25 & 5 & 20 & $80.0 \%$ & $78.2 \%$ & \multirow{2}{*}{0.822} & $57.1 \pm 1.2$ & $54.8-59.4$ & NR \\
\hline Radical surgery & 35 & 8 & 27 & $77.1 \%$ & $74.7 \%$ & & $56.6 \pm 1.1$ & $54.5-58.7$ & NR \\
\hline Overall & 60 & 13 & 47 & $78.3 \%$ & $76.2 \%$ & & $56.8 \pm 0.8$ & $55.2-58.4$ & NR \\
\hline
\end{tabular}

Tab. 2. A comparison between patients who underwent both surgical techniques regarding survival analysis rates (OS and RFS) of patients

DFS and CSS rates in the radical surgery group or fertility preservation surgery group were with no statistically significant differences between both groups regarding tumor recurrence or survival rates (Tab. 2, Figs. 1 and 2).

\section{A comparison of both groups for the pattern of recurrence}

In the FSS group, $5(20 \%)$ patients had recurrence and 3 (12\%) patients died from progressive disease. Most of relapses were limited to the contralateral ovary and only one patient had a disseminated disease with lung metastases. In the radical surgery group, 8 (22.9\%) patients had recurrence and $5(14.3 \%)$ patients died from progressive disease; most of relapses were multiple and disseminated.

\section{Reproductive outcomes in the FSS group}

Of 25 patients who underwent FSS, 18/25 (72\%) attempted to conceive. Infertility was diagnosed in $3 / 18$ (17\%) patients, $15 / 18$ (83\%) pregnancies were recorded, including 13 live births, 1 miscarriage, and 1 intrauterine fetal death. Pregnancy was impossible in 5/25 (20\%) patients due to recurrent disease in the preserved ovary.

\section{DISCUSSION}

Surgical management of young females with ovarian cancer that is primarily limited to the ovary is a challenging issue, particularly if the patient was nulliparous and wishes to preserve her fertility ${ }^{(9)}$. There are few studies comparing radical surgery and fertility-saving surgery, and the management strategies have not been standardized yet ${ }^{(10)}$.

Previous studies have considered cases with high-grade tumors, and stage IC tumors to have a higher risk of relapse and mortality, and that they could not be considered for a fertility-saving approach.

However, recent studies showed that there is no clear evidence to support the fact that radical surgery in stage I EOC of any grade could improve patients' oncological outcomes $^{(9-14)}$, which supports our findings on the benefits of FSS after application of strict precautions and inclusion criteria of patients.

Fruscio et al. confirmed our findings ${ }^{(10)}$.

Mandelbaum et al. showed that oncologic outcomes after FSS were nearly similar to radical surgery in females with stage I, grade 1 and 2 EOC with serous, mucinous or endometrioid histology $\mathrm{y}^{(9)}$.

Jiang et al. showed that cancer specific survival rate was better in the FFS group than that in the radical surgery group; which results from the fact that most high risk patients with higher grade tumors and clear cell morphology underwent radical surgery in their studies ${ }^{(11)}$.

Similar to our data; previous studies which compared fertility sparing and radical surgery in stage I EOC have not found any adverse effects of FSS on patient survival ${ }^{(10,14)}$. Most studies showed that stage I EOC tumors were usually of low grade, had more mucinous histology, occurred in

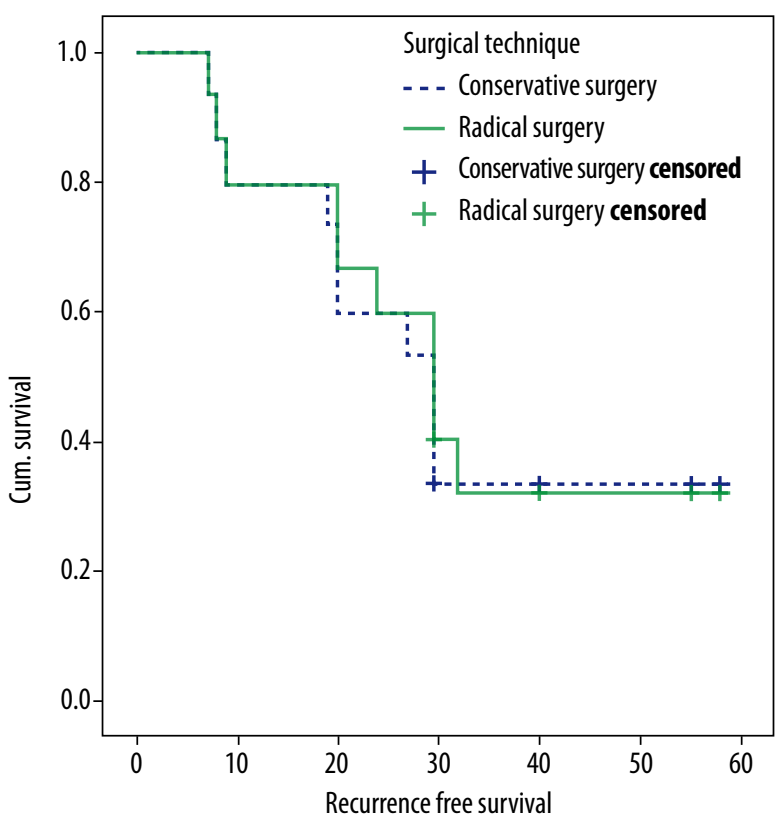

Fig. 1. Recurrence free survival rate of patients operated by both surgical techniques 
younger females and were associated with favorable prognosis, which encourages performing FSS in such categories ${ }^{(10,14)}$. In the present study, we excluded cases with clear cell morphology from FSS due to its high rate of progression. However, a previous study in Japanese patients with stage I clear cell carcinoma of the ovary found that the prognosis of patients with clear cell carcinoma who underwent FSS did not differ from the one in patients with non-clear morphology or patients who underwent radical surgery ${ }^{(15)}$.

In recurrent cases in the FSS group, the pattern of recurrence was localized and less disseminated than in patients in the radical surgery group, who presented with widespread disseminated recurrences, which was similar to the results of Jiang et al. ${ }^{(11)}$ and Bentivegna et al. ${ }^{(16)}$.

This was explained by the fact that recurrence in the preserved ovary is associated with a higher chance of saving patients life by surgery and chemotherapy, which is not inversely affecting the survival of patients who underwent fertility sparing surgery ${ }^{(16)}$.

In the FSS group, we reported an accepted pregnancy and live birth rates, which was comparable with previously published reports of $80 \%$ rate of successful pregnancies after fertility-sparing surgery ${ }^{(10,17)}$.

\section{CONCLUSION}

We concluded that FSS could be an adequate alternative to radical surgery for young females with stage I EOC of serous, mucinous or endometrioid morphology.

Patients must be informed that their younger age is mostly associated with more liability of low-grade tumors with favorable histology, good prognosis in addition to an

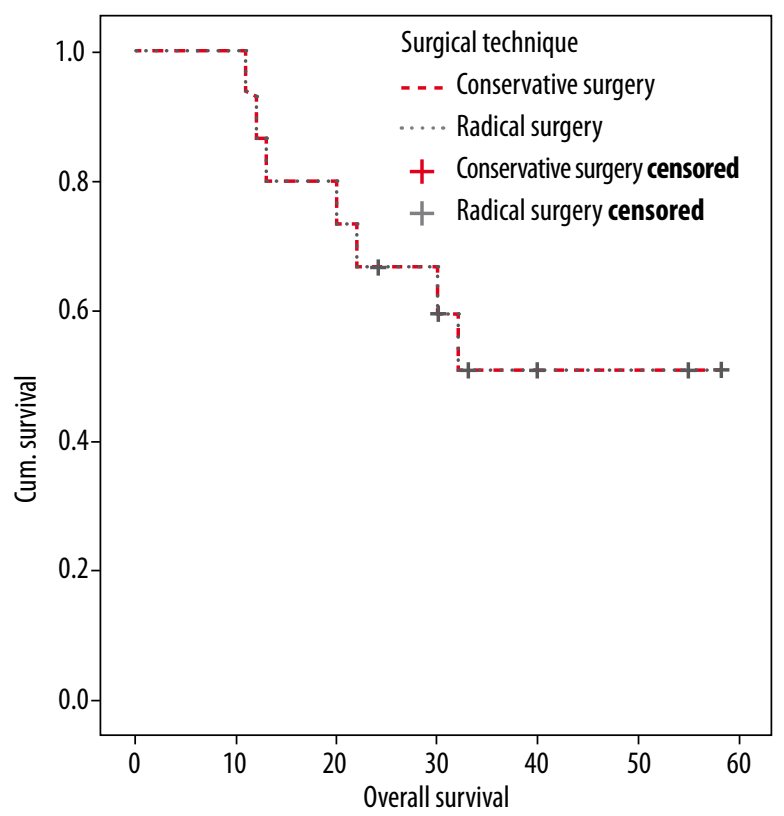

Fig. 2. Overall survival rate of patients operated by both surgical techniques accepted high pregnancy rate, which might increase liability of choosing the option of fertility-sparing surgery.

\section{RECOMMENDATIONS}

Future prospective studies in a large population of patients are needed to compare fertility sparing and radical surgery in stage I EOC in terms of endocrinologic, oncologic and reproductive outcomes for proving the efficacy and safety of fertility sparing surgeries.

\section{Conflict of interest}

The authors do not report any financial or personal affiliations to persons or organizations that could adversely affect the content of or claim to have rights to this publication.

\section{References}

1. Bray F, Ferlay J, Soerjomataram I et al.: Global cancer statistics 2018: GLOBOCAN estimates of incidence and mortality worldwide for 36 cancers in 185 countries. CA Cancer J Clin 2018; 68: 394-424.

2. Kajiyama H, Yoshihara M, Tamauchi S et al.: Fertility-sparing surgery for young women with ovarian endometrioid carcinoma: a multicenteric comparative study using inverse probability of treatment weighting. Eur J Obstet Gynecol Reprod Biol X 2019; 4: 100071.

3. Watanabe $\mathrm{T}$, Soeda S, Nishiyama $\mathrm{H}$ et al.: Clinical and reproductive outcomes of fertility-sparing surgery in stage I epithelial ovarian cancer. Mol Clin Oncol 2020; 12: 44-50.

4. Nasioudis D, Chapman-Davis E, Frey MK et al.: Could fertilitysparing surgery be considered for women with early stage ovarian clear cell carcinoma? J Gynecol Oncol 2017; 28: e71.

5. Eftekhar M, Pourmasumi S, Karimi-Zarchi M: Preservation of ovarian function during chemotherapy and radiotherapy in young women with malignancies. Iran J Reprod Med 2014; 12: 377-382.

6. Yin J, Wang Y, Shan Y et al.: Pregnancy and oncologic outcomes of early stage low grade epithelial ovarian cancer after fertility sparing surgery: a retrospective study in one tertiary hospital of China. J Ovarian Res 2019; 12: 44.

7. Morgan RJ Jr, Armstrong DK, Alvarez RD et al.: Ovarian cancer, version 1.2016, NCCN clinical practice guidelines in oncology. J Natl Compr Canc Netw 2016; 14: 1134-1163.

8. Ledermann JA, Raja FA, Fotopoulou C et al.; ESMO Guidelines Working Group: Newly diagnosed and relapsed epithelial ovarian carcinoma: ESMO clinical practice guidelines for diagnosis, treatment and follow-up. Ann Oncol 2013; 24 Suppl 6: vi24-vi32.

9. Mandelbaum RS, Klar M, Takiuchi T et al.: Fertility-sparing treatment for early-stage epithelial ovarian cancer: contemporary oncologic, reproductive and endocrinologic perspectives. J Obstet Gynaecol Res 2020; 46: 1263-1281.

10. Fruscio R, Ceppi L, Corso S et al.: Long-term results of fertility-sparing treatment compared with standard radical surgery for earlystage epithelial ovarian cancer. Br J Cancer 2016; 115: 641-648.

11. Jiang X, Yang J, Yu M et al.: Oncofertility in patients with stage I epithelial ovarian cancer: fertility-sparing surgery in young women of reproductive age. World J Surg Oncol 2017; 15: 154.

12. Wright JD, Shah M, Mathew L et al.: Fertility preservation in young women with epithelial ovarian cancer. Cancer 2009; 115: 4118-4126.

13. Kajiyama $\mathrm{H}$, Mizuno M, Shibata $\mathrm{K}$ et al.: Recurrence-predicting prognostic factors for patients with early-stage epithelial ovarian cancer undergoing fertility-sparing surgery: a multi-institutional study. Eur J Obstet Gynecol Reprod Biol 2014; 175: 97-102. 
14. Ditto A, Martinelli F, Bogani G et al.: Long-term safety of fertility sparing surgery in early stage ovarian cancer: comparison to standard radical surgical procedures. Gynecol Oncol 2015; 138: 78-82.

15. Satoh T, Tsuda H, Kanato $\mathrm{K}$ et al.; Gynecologic Cancer Study Group of the Japan Clinical Oncology Group: A non-randomized confirmatory study regarding selection of fertility-sparing surgery for patients with epithelial ovarian cancer: Japan Clinical Oncology Group Study (JCOG1203). Jpn J Clin Oncol 2015; 45: 595-599.
16. Bentivegna E, Fruscio R, Roussin S et al.: Long-term follow-up of patients with an isolated ovarian recurrence after conservative treatment of epithelial ovarian cancer: review of the results of an international multicenter study comprising 545 patients. Fertil Steril 2015; 104: 1319-1324.

17. De Vos M, Smitz J, Woodruff TK: Fertility preservation in women with cancer. Lancet 2014; 384: 1302-1310. 